\title{
Cushing's Syndrome in King Chulalongkorn Memorial Hospital: Experience from a Single Tertiary Referral Hospital
}

\author{
Warachit W., Sunthornyothin S. \\ Division of Endocrinology and Metabolism, Department of Medicine, and Excellence Center for Diabetes, Hormone and Metabolism, \\ King Chulalongkorn Memorial Hospital, Bangkok, Thailand
}

\section{Introduction}

Cushing's syndrome (CS) results from excessive cortisol production from adrenal cortex. It can be caused by autonomous cortisol production from adrenal gland or by excess ACTH production either from pituitary or extra-pituitary lesions. Signs and symptoms of CS result from excess endogenous cortisol production. Restoring eucortisolism leads to clinical and biochemical improvement of several conditions including obesity, hypertension, insulin resistance, glucose tolerance, dyslipidemia, bone mineral density (BMD), cognition, psychiatric disorders, and health-related QoL(HRQoL).

\section{Objective}

To assess clinical characteristics, management and outcome of treatment of Cushing's syndrome (CS) in King Chulalongkorn Memorial Hospital (KCMH).

\section{Results}

Of the 86 patients, Cushing's disease(CD) was diagnosed in 47 patients (55\%). 28 patients had adrenal tumor(33\%) and 11 patients(12\%) had ectopic ACTH syndrome. Median age at diagnosis was 38 years old. Median time between first presentation and diagnosis was 12 months, as shown in table 1.

Twenty four percent of the patients had normal body mass index. Skin abnormalities (purplish striae, facial plethora, easy bruising) were found in $21-33 \%$, as shown in table 2 .

\begin{tabular}{|cc|}
\hline Table 2. Clinical features of patients with Cushing's syndrome & Percent \\
\hline Clinical Features & 69 \\
\hline Overweight or obese & 55 \\
\hline Weight gain & 31 \\
\hline BMI $<23 \mathrm{~kg} / \mathrm{m}^{2}$ & 66 \\
\hline Moon face & 52 \\
\hline Dorsocervical fat pad & 33 \\
\hline Wide purplish striae & 21 \\
\hline Facial plethora & 20 \\
\hline Easy bruising & 40 \\
\hline Dyslipidemia & 62 \\
\hline Hypertension & 33 \\
\hline Hypokalemia & 38 \\
\hline Diabetes mellitus & 7 \\
\hline Impaired fasting glucose & 28 \\
\hline Proximal muscle Weakness & 25 \\
\hline Amenorrhea & \\
\hline
\end{tabular}

\begin{tabular}{|c|c|c|c|c|c|}
\hline & & $\begin{array}{l}\text { Cushing's } \\
\text { disease }\end{array}$ & $\begin{array}{l}\text { Adrenal } \\
\text { Cushing }\end{array}$ & $\begin{array}{l}\text { Ectopic } \\
\text { ACTH }\end{array}$ & P-value \\
\hline \multicolumn{2}{|c|}{ Number of patients } & 47 & 28 & 11 & \\
\hline \multicolumn{2}{|c|}{ Median age at diagnosis } & $34(28-42)$ & $42(30-56)$ & $48(44-75)$ & 0.242 \\
\hline \multicolumn{2}{|c|}{$\operatorname{Sex}(F / M)$} & $39 / 8$ & $24 / 4$ & $6 / 5$ & \\
\hline \multicolumn{2}{|c|}{$\begin{array}{l}\text { Time between first symptoms } \\
\text { and diagnosis (months) }\end{array}$} & $12(7-24)$ & $11(4-24)$ & $7(2-12)$ & 0.308 \\
\hline \multicolumn{2}{|c|}{$\begin{array}{l}\text { Median follow up time } \\
\text { (months) }\end{array}$} & $42(17-78)$ & $32(10-58)$ & $5(2-95)$ & \\
\hline \multicolumn{6}{|c|}{$\begin{array}{l}\text { P-value }<0.05 \text { was considered significant for comparison between a group of patients with CD or adrenal CS and a group of patients with ectopic ACTH syndrom } \\
\text { Table 3. Treatment and results of patients with Cushing's disease }\end{array}$} \\
\hline & $\begin{array}{l}\text { Cured after } 1^{\text {st }} \\
\text { surgery }\end{array}$ & $\begin{array}{l}\text { Recurrent } \\
\text { After } 1^{\text {st }} \\
\text { surgery }\end{array}$ & $\begin{array}{l}\text { Persistent after } \\
1^{\text {st }} \text { surgery }\end{array}$ & \multicolumn{2}{|c|}{ er $\begin{array}{c}\text { Cured after multiple } \\
\text { surgeries and/or } \\
\text { radiation }\end{array}$} \\
\hline Macroadenoma & $\begin{array}{c}5 \\
(45 \%)\end{array}$ & - & $\begin{array}{c}6 \\
(55 \%)\end{array}$ & \multicolumn{2}{|c|}{1} \\
\hline Microadenoma & $\begin{array}{c}26 \\
(72 \%)\end{array}$ & $\begin{array}{c}6 \\
(17 \%)\end{array}$ & $\begin{array}{c}10 \\
(28 \%)\end{array}$ & \multicolumn{2}{|c|}{$\begin{array}{c}7 \\
(19 \%)\end{array}$} \\
\hline
\end{tabular}

In $C D, 36$ patients(77\%) had pituitary microadenoma and 11 patients had pituitary macroadenoma(23\%). Twenty six patients(72\%) with pituitary microadenoma were cured after their first transsphenoidal surgeries. All patients with persistent hypercortisolism were cured after subsequent treatments. In patients with pituitary macroadenoma, 5 were cured after their first surgeries. Only one patient had remission of CS after subsequent treatment, as shown in table 3.

In adrenal Cushing's syndrome, cortisol-producing adrenal adenoma was the most common etiology. Median size of tumor was $3 \mathrm{~cm}$. All patients were cured.

Ectopic ACTH syndrome were diagnosed in 11 patients. Primary tumors were located in 8 patients (bronchial and thymic carcinoids, small cell lung cancer, medullary thyroid carcinoma). 7 patients died and 2 patients had persistent hypercortisolism. Only two patients were cured.

\section{Conclusions}

Distribution of CS classification in $\mathrm{KCMH}$ is similar to other reports. $C D$ is the most common etiology of CS. However, higher prevalence of adrenal CS was observed. And prevalence of patients with overweight or obesity as well as skin abnormalities was lower when compared to previous studies. Normal body weight is not uncommon in this center. Gender distribution is predominantly women in CD and adrenal CS. In all subtypes of CS, surgery remained the mainstay of treatment. 